JOURNAL OF SECURITY AND SUSTAINABILITY ISSUES

ISSN 2029-7017 print/ISSN 2029-7025 online

2019 September Volume 9 Number 1

http://doi.org/10.9770/jssi.2019.9.1(10)

\title{
Scopus
}

\section{THE WORLD MARKET OF INTELLECTUAL PROPERTY OBJECTS AND INTERESTS OF NATIONAL SECURITY OF COUNTRIES}

\author{
Vasyl Pankevych ${ }^{1}$, Irina Bilous ${ }^{2}$, Vitaliy Omelyanenko ${ }^{3}$, Yeugene Nagornyi ${ }^{4}$, Andrii Sukhostavets ${ }^{5}$ \\ 1,2Vinnytsia institute of trade and economics of Kyiv national university of trade and economics, \\ Soborna str. 87, Vinnytsia, 21050, Ukraine \\ ${ }^{3 * 4}$ Sumy State Pedagogical University named after A.S. Makarenko, 87 Romenska str, Sumy, 40002, Ukraine \\ ${ }^{5}$ Sumy National Agrarian University, 160 Herasym Kondratiev, Sumy, 40021, Ukraine \\ E-mail: ${ }^{3 *}$ koaduep@gmail.com
}

Received 13 February 2019; accepted 2 July 2019; published 30 September 2019

\begin{abstract}
This scientific paper provides an analysis of the formation and functioning of intellectual property objects. The influence of creation of intellectual property on the level and manifestations of national security of the countries of the world was determined. An analytical study of the current state and leadership in the world market of intellectual property objects has been conducted, the process of protection of intellectual rights and national interests of countries has been identified. Recommendations for combining the concept of national security and the intellectualization of world trade have been formed.
\end{abstract}

Keywords: national security; intellectualization of world trade; intellectual property; patent applications; international patent system; protection of intellectual rights; internationalization of the world economy

Reference to this paper should be made as follows: Pankevych, V.; Bilous, I.; Omelyanenko, V.; Nagornyi, Y.; Sukhostavets, A. 2019. The world market of intellectual property objects and interests of national security of countries, Journal of Security and Sustainability Issues 9(1): 123-137. http://doi.org/10.9770/jssi.2019.9.1(10)

JEL Classifications: F01; F19; F20

\section{Introduction}

One of the most characteristic phenomena of the XXI century is the intellectualization of world trade, that is, the growth of the share of the "intellectual" component in goods and services. The intellectual property rights (IP) has long been an important element of economic development and the object of national security in developed countries, it is this group of countries most actively advocating for strengthening the protection of IP rights and the protection of national security within both bilateral and regional and multilateral treaties.

Most developing countries, unlike the developed ones, historically have not focused on the formation of an IP rights protection system, but the deepening internationalization of the world economy has led to the extreme regulation of IP rights within the multilateral trading system and national security became extremely important for the whole world community.

\section{Literature Survey}

Currently, a certain theoretical and practical scientific base has been accumulated on this issue. The study of the role of innovation and intellectual capital in the economy at the macroeconomic level was carried out by 
such scholars as (Acur \& Englyst, 2006; Ahmad \& Schroeder, 2011; Christensen \& Bower, 1996; Fink, 2001; Nooriaiee \& Pour; 2013; Sabherwal \& Chan; 2001; Taubman, et al., 2012; Sagiyeva et al., 2018; Ma et al., 2018; Zhou, Ch., 2018; Tvaronavičienė, 2019; Koval et al., 2019; Bezpalov et al. 2019; Petrenko et al., 2019). The significance and the need for a deep analysis of this problem is strengthened by the constant expansion of the range of issues affecting the IP rights (activities of mediators: exchanges, auctions, IP clearing companies, the rapid development of Technology Transfer Offices and adherence to national interests and security).

The aim of the study is to comprehensively study the features of the world market of the IP objects and support of national security of countries in the conditions of the world economy system globalization.

\section{Methods}

The development of the system of protection of IP rights and national security can not be achieved without an analysis and conclusions about how the liberalization of trade in intellectual property objects contributes to the development of world trade. These issues are relevant for the Russian economy, since the existing intellectual potential and further innovative development of the economy can become the source of obtaining competitive advantages in the world arena through the effective use of IP objects. The intellectual property acquires the form of intangible assets through the IP system and becomes an integral part of the trade in the knowledge economy (Agreement on Trade-Related Aspects of Intellectual Property Rights (TRIPS Agreement); Tvaronavičieneं, 2018). The most important indicators of the world market of intellectual property objects are:

- purchase and sale of licenses;

- payment of royalties;

- number of patent applications;

- number of registered trademarks;

- registration of other IP objects.

In order to assess the state of the world market of intellectual property objects, it is necessary to consider each of these components.

\section{Results}

The statistical data provided by the WTO allow us to trace the dynamics of changes in payments for the use of intellectual property objects in a regional context and to identify IP regions that are the most involved in the international trade (Table 1).

Table 1. Geographic structure of world exports of IP in terms of received payments for the use of IP objects, billion dollars, US dollars

\begin{tabular}{|c|c|c|c|c|c|c|c|c|c|c|c|}
\hline \multirow{2}{*}{$\begin{array}{l}\text { Indicator / } \\
\text { Region }\end{array}$} & \multicolumn{6}{|c|}{ Volume, billion US dollars } & \multicolumn{2}{|c|}{ World share, $\%$} & \multicolumn{3}{|c|}{ Changes, $\%$} \\
\hline & 2012 & 2013 & 2014 & 2015 & 2016 & 2017 & 2012 & 2017 & $2012-2017$ & 2016 & 2017 \\
\hline Total & 240 & 290 & 295 & 285 & 305 & 295 & 100 & 100 & 4 & 4 & -3 \\
\hline Northen America & 96 & 124 & 128 & 136 & 135 & 131 & 45.6 & 44 & 3 & 0 & -3 \\
\hline South and Central America & 1 & 1 & 1 & 1 & 1 & 1 & 0.3 & 0.4 & 14 & -2 & 19 \\
\hline Europe & 103 & 123 & 120 & 103 & 119 & 113 & 39.5 & 38 & 3 & 5 & -5 \\
\hline EU (28) & 85 & 103 & 99 & 83 & 101 & 98 & 30.7 & 33 & 6 & 12 & -3 \\
\hline CIS & 1 & 1 & 1 & 1 & 1 & 1 & 0.2 & 0.3 & 10 & -10 & 2 \\
\hline Africa & 1 & $>0.01$ & $>0.01$ & $>0.01$ & $>0.01$ & $>0.01$ & 0.1 & 0.1 & -1 & 2 & -9 \\
\hline Near and Middle East & 1 & 1 & 1 & 1 & 1 & 1 & 0.2 & 0.3 & 15 & 8 & -12 \\
\hline Asia & 35 & 39 & 42 & 43 & 50 & 50 & 14.1 & 17 & 8 & 15 & 0 \\
\hline
\end{tabular}

Source: Developed by the authors according to the source World trade statistical review, 2018 
So, the main payments for the use of intellectual property belong to North America and Europe - about $82 \%$ of all payments in total in 2017. Even though the shares of North America and Europe for the given period (20122017) has decreased insignificantly (by 1.6 and 1.5\% respectively), positive growth rates allow us to conclude that North America and Europe will preserve the leading position among exporters in the world IP market in the near future and will continue lobbying their interests in the field of intellectual security in the formation of an international system for regulation of trade in IP objects, first of all, through the signing of preferential trade agreements (PTA).

It should be noted the growing role of Asian countries, whose growth was $2.9 \%$ from 2012 to 2017 . The analysis of the dynamics of statistical data confirms the conclusion that since 2002, the role of this region in the world trade in IP has increased significantly, and in 2016 there was a significant increase (15\%), compared with the region of North America, which has zero dynamics (World trade statistical review, 2018). Nevertheless, a sharp deceleration in growth was observed in Asia in 2017 compared to the previous year, which can be explained by the intensification of the regimes of IP trade in relation to this region, and, as a consequence, the decline in participation in world trade in intellectual property and the beginning of trade disputes between the United States and China (Drobyazko S., 2017; Drobyazko S., etc., 2019).

The positive dynamics was observed in the Near and Middle East, South and Central America and CIS countries. However, there was reduction of payments for the use of intellectual property in 2017, mainly in the countries of the Middle East, where the reduction was $12 \%$ compared with the previous year. The negative growth rates in 2017 were also observed in the African Region (-9\%), where this trend is long term during 2012-2017, indicating the passive participation of the region in international trade in IP objects and fall in IP security of countries.

So, the world leaders among recipients of license fees and royalty payments are mainly developed countries such as USA, Japan, South Korea and, of course, the EU (Fig. 1). 


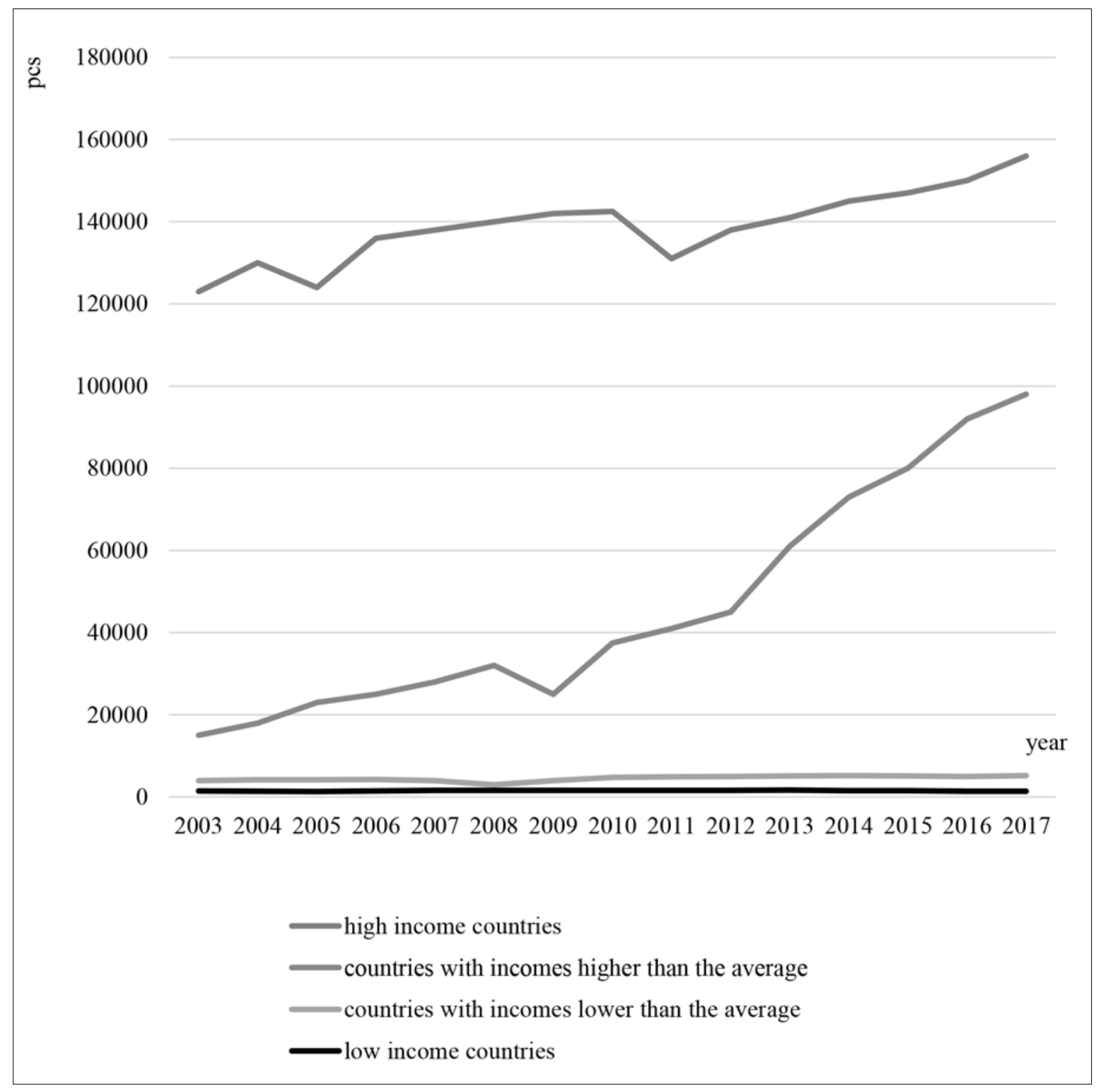

Fig. 1. The main recipients of payments for the use of IP objects for 2003-2017, \%

Source: Developed by the authors according to the source International Trade Statistics Yearbook

We note that the share of the US, EU and Japan is a total of $86 \%$ of global revenues from license fees and royalties. The China share among global recipients is not so great and is less than one percent. China is ranked fourth among the major world payers of royalties and license fees, which makes it the largest consumer of IP in developing countries and countries actively form national intellectual security system (Table 2). 
Table 2. The main countries payers of royalties and license fees in 2017

\begin{tabular}{|c|c|c|}
\hline No. & Importer & Amount of payments, mln. US dollars. US dollars \\
\hline 1 & EU & 143478 \\
\hline 2 & US dollars & 42141 \\
\hline 3 & Singapore & 22230 \\
\hline 4 & China & 22614 \\
\hline 5 & Japan & 20916 \\
\hline 6 & Switzerland & 12351 \\
\hline 7 & Canada & 10229 \\
\hline 8 & South Korea & 10369 \\
\hline 9 & Russia & 8039 \\
\hline 10 & Thailand & 3971 \\
\hline
\end{tabular}

Source: WIPO Copyright Treaty (WCT)

In addition, we can see from Table 2 that the number of world taxpayers does not qualitatively differ from the world's recipients of license fees and royalty payments, with the exception of some nuances. Among the paying countries, unconditional leadership belongs to the European Union ( $\$ 143,476$ million US dollars), and not to the USA (42,141 million dollars), which occupy only the second position.

On the basis of these data, it is possible to make a logical conclusion that it is precisely such states as the US, EU countries and Japan that effectively manage existing intellectual property objects on a global scale, have stable positions in the field of national security, and companies of these countries competently use the competitive advantages created both on the international and on the domestic market. According to WIPO statistic data, the highest number of applications for patent protection is noted in high-income countries, due to the orientation of most of these countries towards the innovative type of economic development. However, one can not ignore an important tendency: starting in 2012, there is a sharp increase in the number of applications from the group of countries with a higher incomes than average and a reduction of the gap with the leaders of the countries by this indicator (Fig. 2). To explain this phenomenon, a deeper analysis of the countries of the world and IP objects should be conducted.

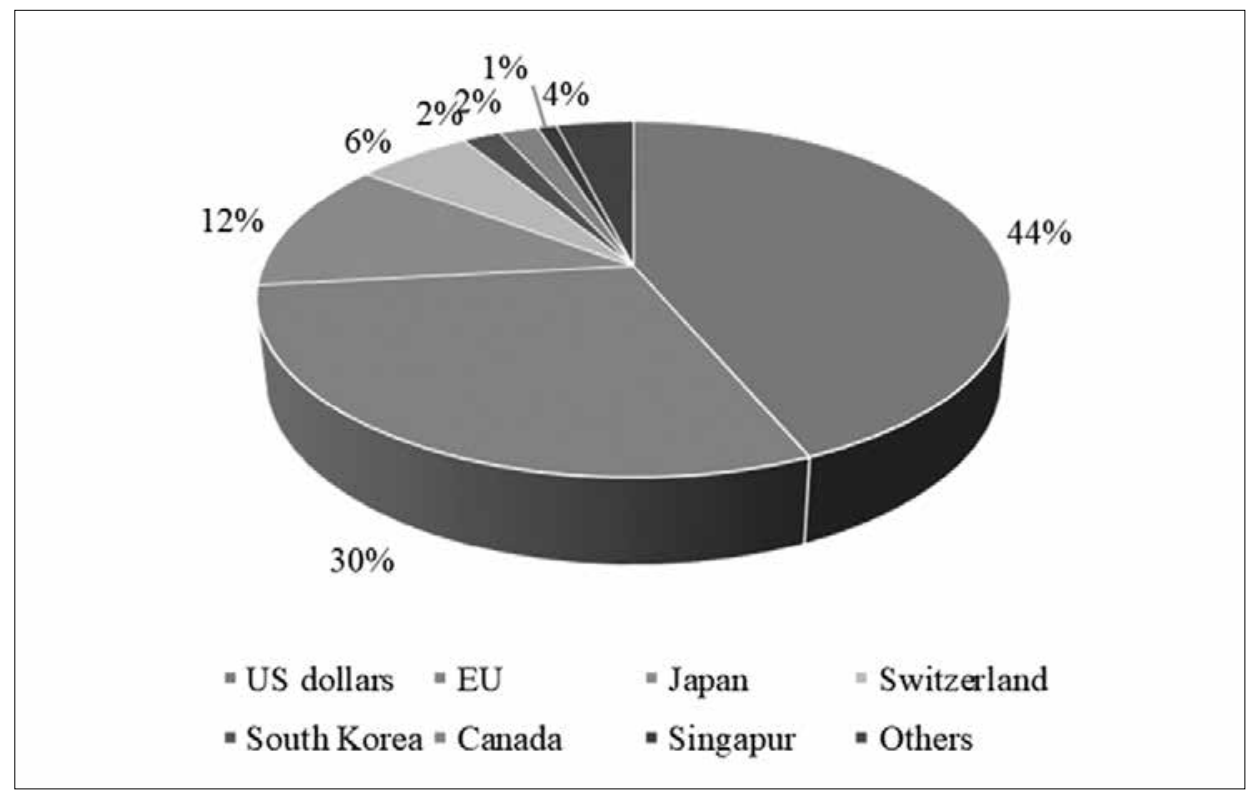

Fig. 2. Number of patent applications by country group (including PCT applications) in 2003-2017

Source: Developed by the authors according to the source World Intellectual Property Indicators, 2018 
Data presented in Fig. 2 confirm that in recent times international cooperation has intensified in some areas. This trend is most clearly represented at the level of private international patenting. For 1998 to 2016, the number of applications for a patent, including in accordance with the International Patent Cooperation Treaty (PTC), has consistently increased, with the exception of only the crisis of 2009. At that, the United States became the undisputed leader in the number of international applications filed under the PCT procedure by the end of 2017. Figure 3 shows data from other countries that are leading on this indicator in 2017.

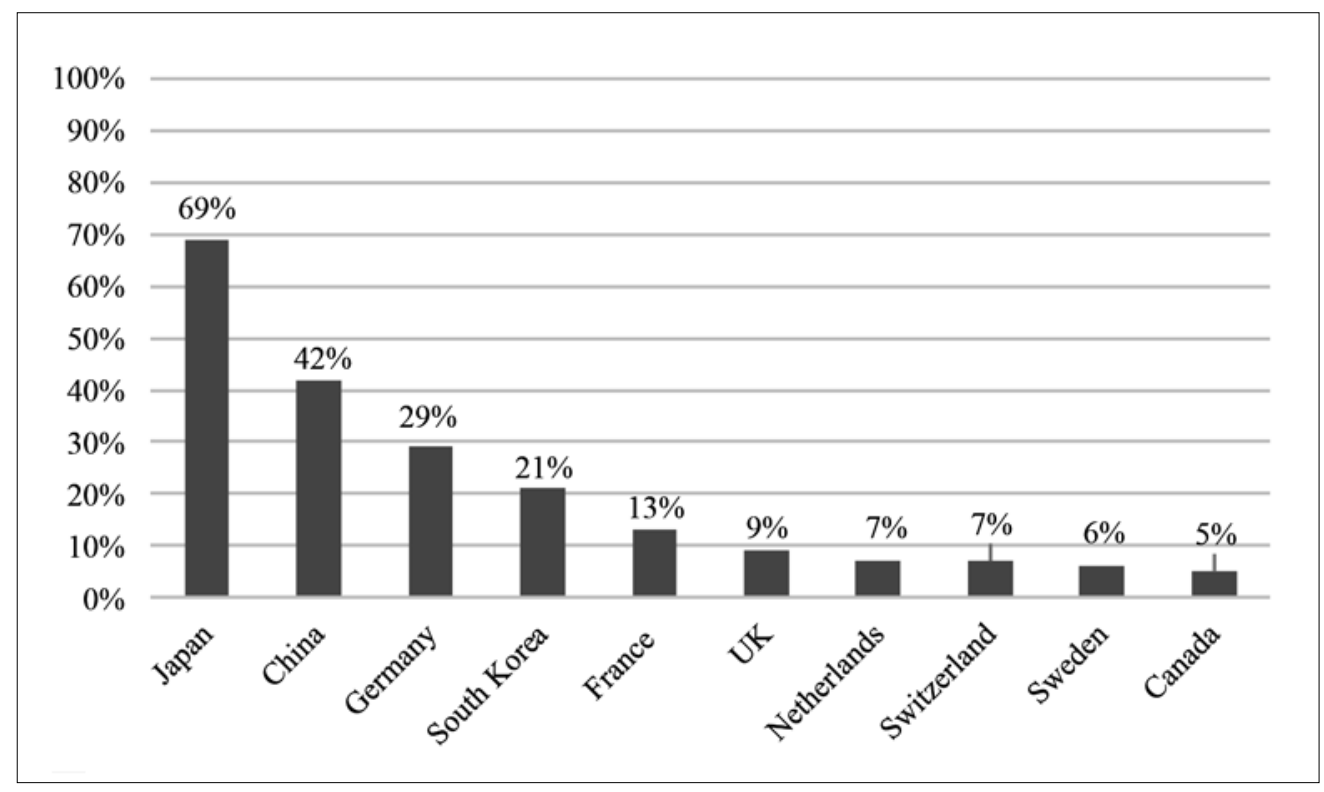

Fig. 3. Top 10 world leaders in 2017 (except for USA) that filed an international application under the PCT procedure, $\%$ (the volume of applications for international patent from USA $(100 \%)$ was taken as the basic indicator)

Source: Developed by the authors according to the source World Intellectual Property Indicators, 2018

Fig. 3 graphically shows that the demand for internatinal protection of the IP objects and formation of the intellectual safety using the patenting system is basically formed by the developed countries, which companies lead active activities in the world market. In addition, it is also promoted by regulatory systems based on the international agreements and recommedations. In addition, fig. 3 shows that the list is provided mostly by the countries with the high level of income (China is the exception) The most active use of the international patent system, with the exception of the USA, was demonstrated by the representatives of Japan, Germany and China, while the number of applications from Japan exceeds similar figures in Germany more than 2 times, but still does not reach the level of the United States.

The statistical analytics presented at the end of 2017 does not reflect significant changes among the number of those most actively using the system of patenting of countries, except perhaps one important fact, clearly shown in Fig. 4. 


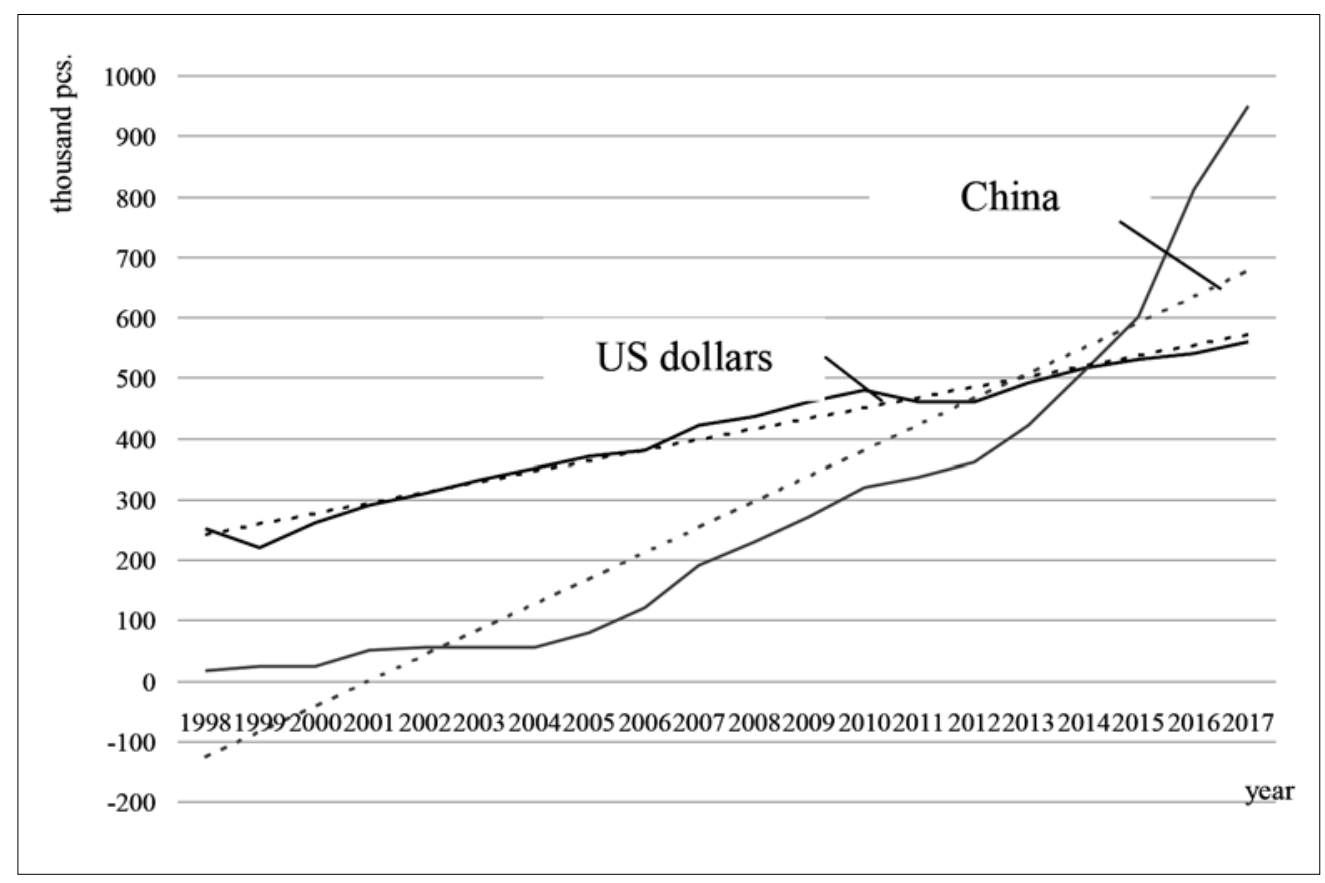

Fig. 4. The total number of patent applications in the US and China, including applications under the PCT procedure

Source: Developed by the authors according to the source World Intellectual Property Indicators, 2018

So, from 2013 to 2014, China became the world leader in the number of patent applications received, being ahead of the USA. At the same time, analyzing the growth rates of this indicator in the given countries for 2013-2017, and given the significant figures shown by China, one can assume that China's leadership in the near future will intensify (Table. 2).

Table 2. The growth rates of the number of patent applications in the USA and China over 2013 to 2017

\begin{tabular}{|c|c|c|c|c|}
\hline \multirow{2}{*}{ Year / Indicator } & \multicolumn{2}{|c|}{ Number of applications, pieces } & \multicolumn{2}{|c|}{ Growth rates, \% } \\
\cline { 2 - 5 } & US dollars & China & US dollars & China \\
\hline 2013 & 490226 & 391177 & - & 35 \\
\hline 2014 & 503582 & 526412 & 3 & 24 \\
\hline 2015 & 542815 & 652777 & 8 & 26 \\
\hline 2016 & 571612 & 825136 & 5 & 13 \\
\hline 2017 & 578802 & 928177 & 1 & \\
\hline
\end{tabular}

Source: Developed by the authors according to the source World Intellectual Property Indicators, 2018

A similar situation is observed in the number of applications for trademarks: in 2017, China received almost 5 times more applications than the US Patent and Trademark Office. So, we can conclude that China has not only become a world center for the protection of intellectual property, but also maintains high growth rates, contributing to consolidating this leadership and strengthening the level of national security. Exceptions can only serve as indicators of the number of applications for registration of industrial designs, which show a negative growth rate, but this trend is characteristic not only for China, but also for the world as a whole.

Another global trend is the increase in the number of patent applications for inventions from 1.4 million in 2003 to 2.14 million in 2013, the first time exceeding the figure of 2 million. Today, according to the latest data of WIPO (World Intellectual Property Organization), more than 2.7 million patent applications were filed in 2017. Such significant growth took place in several stages: in 1980s, largely at the expense of Japan, the leadership later passed to the countries of Europe and the United States of America, then in the 1990s the Republic 
of Korea joined them and, relatively recently, but demonstrating unprecedented growth rates, as previously presented, China.

At the same time, in 2002 and 2009, there was a decline in the world - the reduction in the number of applications for a patent was about $1.1 \%$ and $3.5 \%$ respectively, compared to the previous year, due to the reduction of world GDP and crisis phenomena in the world economic system, first of all - the stagnation of industrial production, which has a direct correlation with the intensification of patent activity - but in subsequent years there was a significant increase, in 2017 by 4,5\%. Thus, the long-term trend in changing the number of applications for patent protection in the new millennium remains upward, which is due to a larger increase in the number of applications filed with US Patent Offices and, in the first place, China (The Global Information Technology Report).

There are several reasons for such a rapid growth of patent operations, including those that are specific to certain countries and industries. However, two key factors can be distinguished (Yang et al., 2015).

First, the analysis of such categories of global patents as "initial applications", which means the registration of a practically new invention, and "further applications" - applications for the same invention in different countries - shows that the latter provide a little more than half of this growth over the last 12-15 years.

Secondly, given the pace of change in world expenses on $\mathrm{R} \& \mathrm{D}$, we can conclude that the growth of patenting was mainly due to investment in knowledge in the world as a whole. However, trends in patenting and spending on R\&D differ markedly in different countries and regions, with important features of conduction of innovation activities by resident companies (Lii \& Kuo, 2016).

The rapid increase in the number of patent applications, in turn, raises concerns about the growth of patent portfolios of individual TNCs that are eligible for a priority application and impede innovation by jointly-owned companies, including small and medium-sized businesses (joint innovations), which leads to slowing down scientific and technological progress and the development of the world economy, given the concentration of advanced technologies in the hands of several world corporations.

The world trade in patents shows robust growth in the field of so-called sophisticated technologies. Economists define complex technologies, such as those that consist of a multitude of individual inventions with the possibility of a broad patent holder, that is, those that include several patents, the owners of which are often several individuals. For example, sophisticated technologies include the majority of ICTs, which have been experiencing rapid growth over the past three decades. However, economic research shows that the rapid growth of patenting in the field of sophisticated technologies and subsequent license trading are due to changes in the company's innovative strategies (Limba, et al., 2019). Patents allow companies to specialize in any area, which in turn allows them to be both more efficient and innovative. In addition, patents allow companies to flexibly manage their intellectual resources: determine what should be kept in secret and what can be sold to maximize profits while maintaining an appropriate level of security (Zambon, 2017).

The research in the field of semiconductor manufacturing showed that firms are actively expanding the patent portfolios. One of the reasons for this is the desire of the company to provide freedom of activity in its innovation space and acquire ownership of intellectual property. Another factor motivating the formation of patent portfolios is the desire of companies to strengthen their positions in the negotiations in harmonizing the conditions of mutual licensing, which are often needed for the commercialization of new technologies.

In addition to this industry, the growth of patent portfolios is noted in other high-tech sectors of ICTs, in particular in the field of telecommunications, software, audio and video production, optics and the relatively young sectors of smartphone and tablet computers. However, despite the fact that these "portfolio races" often occur in industries that are an important driving force behind technological progress, there are fears that they can slow down or even counteract cumulative innovation processes. In particular, entrepreneurs with a large number of 
cross-patent rights may refuse further research or postpone plans for the commercialization of promising technologies (Stankevičius \& Lukšaitè, 2016).

However, with a very thorough study of the relationship between patenting and the intensification of international trade in licenses, very little attention is paid to the study of demand for the protection of trademarks. According to the authors, this study may contribute to obtaining important information about the world of IP objects trading, given the tendency to intellectualize the economy and the growing role of this IP object.

As presented in Fig. 5, there was noted a reduction in the number of applications for registration of trademarks (absolute growth rates made up 5\%) only in crisis 2009, however, in 2012 there is a sharp increase in this indicator (an increase of 9\%) and a significant excess of the pre-crisis level already in 2013 with further growth.

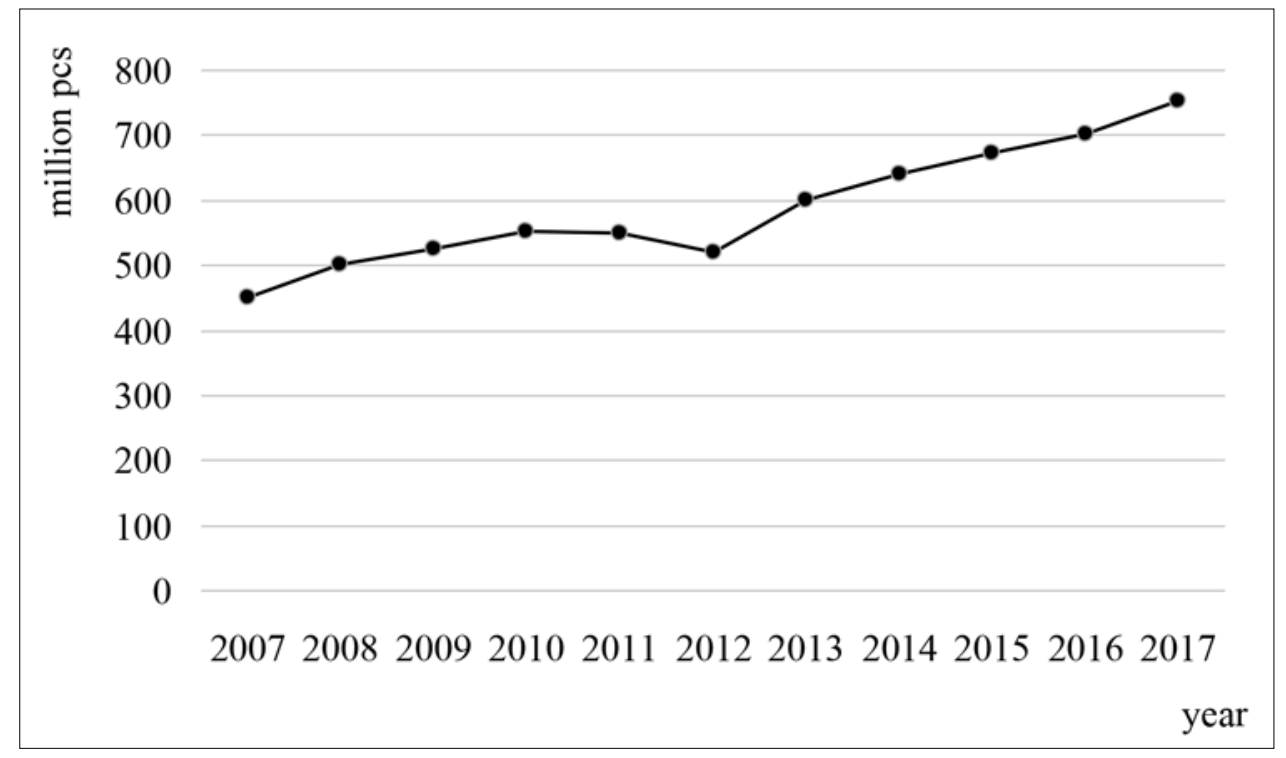

Fig. 5. The dynamics of the number of applications for trademarks in the world, 2004-2016

Source: Developed by the authors according to the source World Intellectual Property Indicators, 2018

Today's realities are that more than half of global applications for trademark registration go to countries with middle and low income, Latin America and Caribbean countries are slightly expanding, and patent offices in Asia are prominent recipients of applications (Leese \& Wittendorp, 2017).

For a more in-depth analysis of the global demand for trademark protection, it's worth considering how the same indicator has changed specifically for markets in some countries.

The active development in the field of trademark protection was received by the Japanese Patent Office at the beginning of the 1970's, and in the US Department of Patents and Trademarks in the middle of the decade, other countries began to develop the institutes and mechanisms for registration of trademarks later (Schuelke, 2018). Fig. 6 shows the dynamics of filing applications for registration of trademarks in some patent offices in the world. 


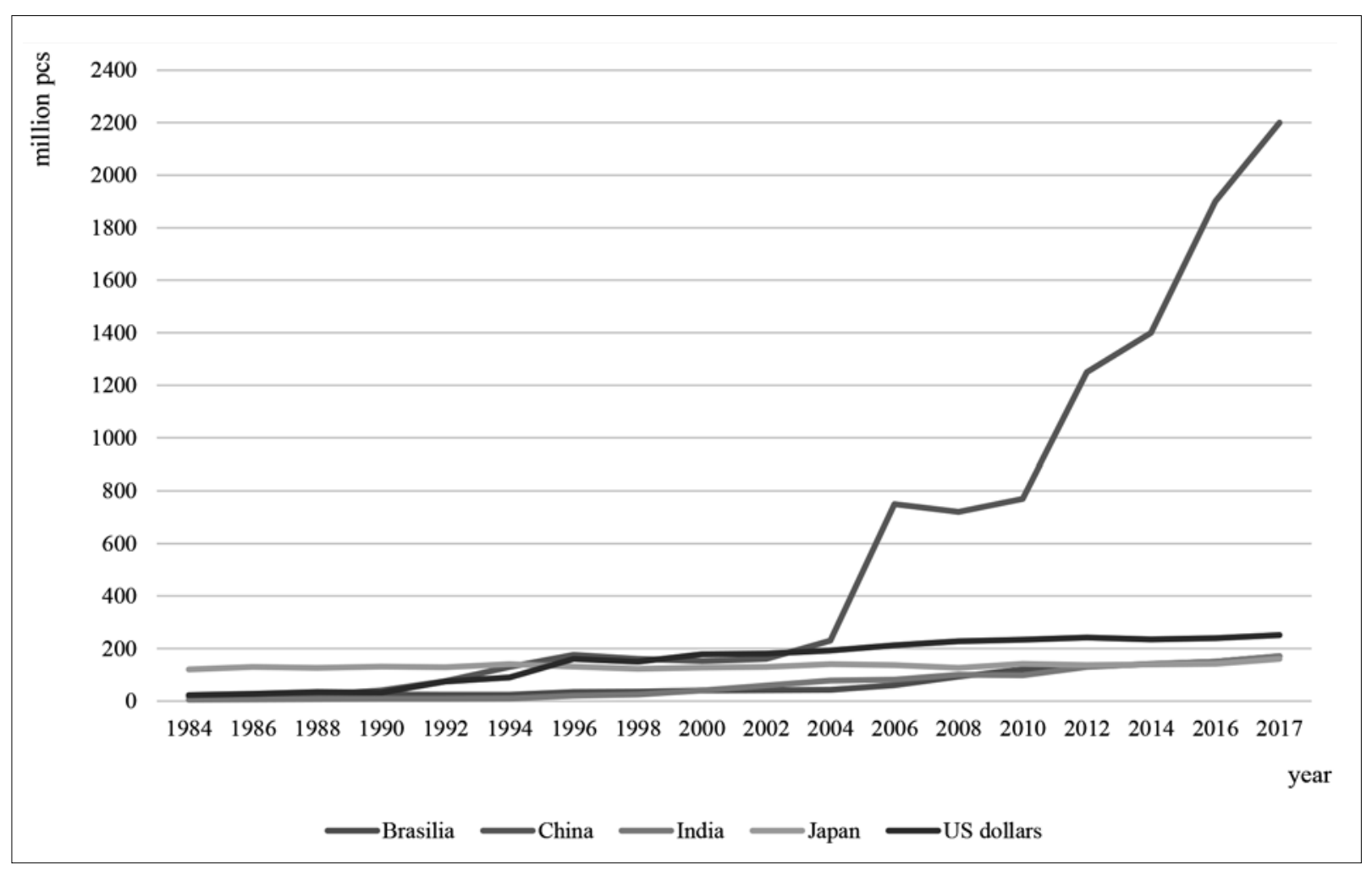

Fig. 6. Number of applications for trademarks in national departments, 1980-2016

Source: Developed by the authors according to the source Handbook of Statistics, 2018

As can be seen from the data presented, the Japanese Patent Office was the unconditional leader in the number of applications for trademarks received by the mid-1990s. However, in 1995, there are roughly the same level of applications in the departments at once in three countries: USA, Japan and China. After that, since 2001, there has been a reduction in applications in Japan, and China becomes the world leader in the number of received trademark applications, and today, as in the case of patent applications, it significantly outpaces the US Patent Office for this indicator.

This is partly due to the policy pursued by the Chinese government, as well as the high rates of growth of the country's economy during this period. Given the current level of globalization of the world community, the crisis of 2008-2009 significantly affected the number of applications received by the Chinese department (negative growth rate of $2 \%$ was observed), however, the pre-crisis level was quickly reached, and there has been a sharp increase in the number of applications for registration of trademarks since 2013.

Compared to Chinese and American departments, similar departments from Brazil, Japan and India receive substantially fewer applications, but these economies are among the 20 leading countries in the world in terms of the number of patent applications (Patent Cooperation Treaty, PCT).

Thus, the data presented in Figures 5 and 6 allows us to conclude that increased activity in the field of registration of trademarks in high-income countries began at 10-15 years earlier than in middle-income countries, but a sharp increase in the number of applications is seen in the last group of countries, and the global demand for trademarks continues to grow steadily since 2009. This trend can serve as a factor in intensifying the participation of these countries in the worldwide turnover of IP objects and strengthening the level of national security.

However, it should be noted some difficulties and mistakes in the comparison of data from the patent offices of the world due to the difference in the institutional mechanisms of registration of trademarks, in particular - dif- 
ferences in the system of filing applications. There is a system for filing applications for a single class of goods and services (in the WIPO terminology it is called a single-class filling system) and a system for application for several classes of goods and services (in WIPO terminology, multi-class filling system). In the case of use of the first one (one class), the applicant shall submit a separate application for each class of goods and services in which the trademark will be used. Such a system is used, for example, in Brazil and China. The second system (the multi-class one) is characterized by the fact that the applicant submits a single application, which specifies all classes requiring protection (Jorfi et al., 2017; WIPO Copyright Treaty (WCT). This mechanism is used in most European countries, USA, Japan, and others.

So, direct comparison of the number of applications in different departments, in other equal conditions, will always outweigh the amount for the benefit of countries that use the system for application for a single class of goods and services, that is, such a comparison gives false results. This can be avoided by comparing volumes based on the number of classes on which applications are submitted, which allows the WIPO statistical database system to be used for analysis (Dzwigol, H., Aleinikova, O., Umanska, Y., Shmygol, N., \& Pushak, Y., 2019).

Another problem in comparative analysis of statistical data on the number of applications submitted for registration and protection of a trademark is the requirement for proof of use of the trademark before registration. In countries where legislation is loyal and this requirement is not forthcoming, manufacturers can file multiple trademarked applications without planning to use them immediately, or just creating favourable conditions for the market entry of similar goods, increasing barriers to entry for competitors (Schwab, 2016)

Among the important factors influencing the number of applications for trademarks, it is necessary to distinguish the rates of economic growth, which are directly correlated with the growth of investment in innovation and, as a consequence, leading to activation of the activities in the field of IP. Obviously, by creating an innovative product, the company seeks to maximally protect its product, while using the symbiosis of various ways of protection of intellectual property: after the expiration of the patent, trademarks permit the life cycle of the patented product to be extended (Holovatyi, M.,2014).

It should be noted that in the process of deepening industrialization in a group of developing countries and gradually increasing the share of service sectors in the economies of low and middle income countries, the use of the registration system, including international trademarks, is being developed and intensified. The growth rates are mainly due to the development of business, communications and financial services, as well as health care services. However, the share of applications for trademarks on products still exceeds the share of applications for trademarks for services, and this situation is noted even in countries that are in the post-industrial stage of economic development with a high proportion of service sectors (USA, UK, Australia, France, Germany, etc.) (Isoda, 2018). At the same time, more applications for trademarks are served abroad.

Due to the globalization of the world economy, the development of the Internet and the pursuit of economic activity in the virtual space has a special impact on the growth of the use of trademarks. Manufacturers understand that without being able to evaluate the goods physically, the buyer will try to employ other methods to check the quality and characteristics of the intended purchase, and a well-known and familiar trademark can play a a decisive role in making a decision (Nielsen et al., 2017).

With regard to the world market of such objects as useful models and industrial designs, then Table 4 presents the main participants in this market and the demand that they put on these objects. 
Table 4. Geographical division of applications for IP in 2016

\begin{tabular}{|c|c|c|c|c|}
\hline Country & Patents & Trademarks & Industrial designs & Useful models \\
\hline China & 928177 & 2104534 & 564555 & 868511 \\
\hline US dollars & 578802 & 341902 & 35378 & - \\
\hline Germany & 65965 & 70554 & 7392 & 7095 \\
\hline Japan & 325989 & 124602 & 29738 & 9184 \\
\hline South Korea & 210292 & 160644 & 64574 & 424 \\
\hline France & 16533 & 90674 & 4782 & 2497 \\
\hline Italy & 9382 & 40016 & 5084 & - \\
\hline UK & 23040 & 54525 & 9309 & - \\
\hline India & 42854 & 222235 & 1138400 & 948900 \\
\hline
\end{tabular}

Source: Developed by the authors according to the source World Intellectual Property Indicators, 2018

Totally these countries have: $83 \%$ of all applications for patents, $44 \%$ of applications for trademarks, $63 \%$ of applications for industrial designs. At the same time, China accounted for $49 \%$ of world demand for industrial designs and $92 \%$ of world demand for utility models. So, the largest Chinese TNCs, along with several national universities, are leaders in the world market for IP objects.

\section{Discussion}

It is worth noting that not only Chinese but also large multinational companies around the world seek to protect IP abroad, which has been reflected in the increase in the number of international applications. The growth in demand for services and the expansion of the geographical coverage of the Patent Cooperation Treaty system, as well as Madrid (trademark registration) and the Hague systems (registration of industrial prototypes) (European Innovation Scoreboard (2018).

To summarize, there are several reasons for the growth of the world market of IP objects. One of them is an increase in the role of intellectual property in international economic relations. This tendency promotes the aspiration of the right holders to expand the geographical coverage of the application and, of course, the protection of IP objects. In addition, the growth of world trade in industrial property is due in part to the involvement of an increasing number of countries in world trade and as a consequence of the registration of the same invention in different countries ("secondary" applications) (Bigo, 2001). The globalization has contributed to the strengthening of IP protection regimes in many countries and the emergence of special interest of economic entities in enterprises that are based on knowledge and information.

The development of technologies (nanotechnology, bioengineering, ICT, etc.) and an increase in the domestic demand of innovative enterprises, the behaviour of which reflects a change in the role of intellectual property in the economy at the national level is equally important. The growth of R\&D expenditures in certain industries, coupled with a reduction in the lifecycle of many products, provided additional incentives for companies to use existing IP rights as competitive advantages (International Convention for the Protection of Performers, Producers of Phonograms and Broadcasting Organizations).

So, the analysis of the market of IP objects shows that in the last two decades there has been a sharp increase in the number of patent applications, trademark applications and other types of IP, along with minor fluctuations in license payments for royalty rates. This conclusion suggests that the global IP market is at an early stage of development and is only being formed. The reason for this phenomenon is not only the globalization of the world economy, but also the active activities of TNCs, which place their research units in different countries around the world. However, it is almost impossible to estimate how much of the intellectual property in world trade has grown in relative terms, as the innovations, which are often associated with them, are accompanied by technological breakthroughs and international exchange of knowledge. 


\section{Conclusions}

One of the key indicators of the intensification of international intellectual property trade is the scale of demand for IP rights, including international ones. The highest number of applications for patent protection is noted in high-income countries, due to the orientation of most of these countries towards the innovative type of economic development.

There is also an increase in the number of applications from the group of countries with a higher incomes than average and a reduction of the gap with the leading countries by this indicator. At the same time, China is demonstrating the highest rates of increase in the number of applications for both patent protection and trademark registration. According to the author, China has not only become a world center for the protection of intellectual property and national security, but also maintains high growth rates, contributing to consolidation of leading positions in the near future. The analysis of the "initial applications" and "further applications" for obtaining a patent makes it possible to draw a very important conclusion that applicants are increasingly seeking to protect their intellectual property abroad and all in more countries, reflecting the growth of economic integration. Given the pace of change in world expenses on R\&D, we can conclude that the, the growth of patenting was mainly due to investment in knowledge in the world as a whole.

The globalization has contributed to the strengthening of IP protection regimes in many countries and the emergence of special interest of economic entities in enterprises that are based on knowledge and information.

The development of technologies (nanotechnology, bioengineering, ICT, etc.) and an increase in the domestic demand of innovative enterprises, the behaviour of which reflects a change in the role of intellectual property in the economy at the national level is equally important. The countries such as the United States, EU and Japan most effectively manage existing intellectual property objects globally, and companies in these countries are competent to use the competitive advantages they create in the international and domestic markets. The growth of R\&D expenditures in certain industries, coupled with a reduction in the lifecycle of many products, provided additional incentives for companies to use existing IP rights as competitive advantages. The internationalization is a major factor in the growth of demand for such IP forms as trademarks and patents.

\section{References}

Acur, N., \& Englyst, L. (2006). Assessment of strategy formulation: How to ensure quality in process and outcome.International Journal of Operations \& Production Management, 26(1), 69-91. https://doi.org/10.1108/01443570610637021

Agreement on Trade-Related Aspects of Intellectual Property Rights (TRIPS Agreement) (Authentic text) [Electronic resource] / World Trade Organization. - Electronic data. Available on the Internet: https://www.wto.org/english/tratop_e/trips_e/t_agm0_e.htm

Ahmad, S., \& Schroeder, R. G. (2011). Knowledge management through technology strategy: Implications for competitiveness.Journal of Manufacturing Technology Management, 22(1), 6-24. https://doi.org/10.1108/17410381111099789

Bezpalov, V.V., Fedyunin, D.V., Solopova, N.A., Avtonomova, S.A., Lochan, S.A. (2019). A model for managing the innovation-driven development of a regional industrial complex. Entrepreneurship and Sustainability Issues, 6(4), 1884-1896. http://doi.org/10.9770/ jesi.2019.6.4(24)

Bigo, D. (2001)). The Mobius Ribbon of Internal and External Security(ies). In M. Albert, D. Jacobsen, \& Y. Lapid, Identities, Borders, Orders -Rethinking International Relations Theory (pp. 91-136). London: University of Minnesota Press

Christensen, C. M., Bower, J. L. (1996). Customer power, strategic investment, and the failure of leading firms. Strategic management journal, 17(3), 197-218. https://doi.org/10.1002/(SICI)1097-0266(199603)17:3<197::AID-SMJ804>3.0.CO;2-U

Drobyazko S. (2017). Formation of competitive positions as providing of economic security of insurance companies // International scientific journal “Internauka”. Series: “Economic Sciences”, 2017, №2. URL: https://doi.org/10.25313/2520-2294-2017-2-4784

Drobyazko S., Hryhoruk I., Pavlova H., Volchanska V., Sergiychuk S. (2019). Entrepreneurship innovation model for telecommunications enterprises. Journal of Entrepreneurship Education, Volume 22, Issue 2, 2019. URL: https://www.abacademies.org/articles/ entrepreneurship-innovation-model-for-telecommunications-enterprises-8097.html 
Dzwigol, H., Aleinikova, O., Umanska, Y., Shmygol, N., \& Pushak, Y. (2019). An Entrepreneurship Model for Assessing the Investment Attractiveness of Regions. Journal of Entrepreneurship Education, 22(1S), 1-7.

European Innovation Scoreboard (2018). Available on the Internet: http://ec.europa.eu/growth/content/european-innovation-scoreboard2018-europe-must-deepen-its-innovation-edge_en

Fink, C. (2001). Intellectual Property Rights. Preferential Trade Agreement Policies for Development: A Handbook (eds J.-P. Chauffour, J.-Ch. Maur). - Washington, DC: World Bank. http://hdl.handle.net/10986/2329

Handbook of Statistics (2018). UNCTAD Available on the Internet: https://unctad.org/en/PublicationsLibrary/tdstat43_en.pdf

Holovatyi, M. (2014). Multiculturalism as a means of nations and countries interethnic unity achieving. Economic Annals-XXI, 11-12, 15-18. URL: http://nbuv.gov.ua/UJRN/ecchado_2014_11-12_5

International Convention for the Protection of Performers, Producers of Phonograms and Broadcasting Organizations (Authentic text) [Electronic resource] World Intellectual Property Organization. Available on the Internet: http://www.wipo.int/wipolex/en/treaties/text. jsp?file_id=289795

International Trade Statistics Yearbook. Available on the Internet: https://www.un-ilibrary.org/international-trade-and-finance/ international-trade-statistics-yearbook-ser-g_e9aba95b-en

Isoda, V. (2018). UK-EU relationship after Brexit: an exercise in scenario-building, Journal of Security and Sustainability Issues 8(1): 33-43. https://doi.org/10.9770/jssi.2018.8.1(3)

Jorfi, S., Nor, K.M., \& Najjar, L. (2017)). An empirical study of the role of IT flexibility and IT capability in IT-business strategic alignment. Journal of Systems and Information Technology, 19(1/2), 2-21. https://doi.org/10.1108/JSIT-10-2016-0067

Koval, V., Duginets, G., Plekhanova, O., Antonov, A., Petrova, M. (2019). On the supranational and national level of global value chain management. Entrepreneurship and Sustainability Issues, 6(4), 1922-1937. http://doi.org/10.9770/jesi.2019.6.4(27)

Leese, M., \& Wittendorp, S. (2017). Security/Mobility: Politics of Movement. Manchester: Manchester University Press. URL: https:// www.academia.edu/31402601/Leese_M_and_Wittendorp_S_eds._2017._Security_Mobility_Politics_of_Movement_Manchester_ Manchester_University_Press

Lii, P., \& Kuo, F.I. (2016). Innovation-oriented supply chain integration for combined competitiveness and firm performance. International Journal of Production Economics, 174, 142-155. http://doi.org/10.1016/j.ijpe.2016.01.018

Limba, T., Stankevičius, A., Andrulevičius, A. (2019). Industry 4.0 and national security: the phenomenon of disruptive technology, Entrepreneurship and Sustainability Issues 6(3): 1528-1535. https://doi.org/10.9770/jssi.2019.6.3(33)

Ma, D., Ye, J., Zhang, Y (2018). Can Firm Exploit Economic Gains from Eco-innovation? An Empirical Investigation of Listed Companies in China. Transformations in Business \& Economics, 17, No 2 (44), 38-53

Nielsen, C., Ricceri, F., Guthrie, J., \& Dumay, J. (2017). The past, present, and future for intellectual capital research: an overview. In The Routledge Companion to Intellectual Capital, (pp.1-17). Routledge.

Nooriaiee, M.H., \& Pour, M.S. (2013). Studying role of information systems at strategy formulation process. Journal of Basic and Applied Scientific Research, 3(4), 368-373.

Patent Cooperation Treaty (PCT) (Authentic text) [Electronic resource] / World Intellectual Property Organization. - Electronic data. Available on the Internet: http://www.wipo.int/wipolex/en/treaties/text.jsp?file_id=288637

Petrenko, Y.; Vechkinzova, E.; Antonov, V. (2019). Transition from the industrial clusters to the smart specialization of the regions in Kazakhstan. Insights into Regional Development, 1(2), 118-128. https://doi.org/10.9770/ird.2019.1.2(3)

Sabherwal, R., \& Chan, Y.E. (2001). Alignment between business and IS strategies: A study of prospectors, analyzers, and defenders. Information Systems Research, 12(1), 11-33. http://doi.org/10.1287/isre.12.1.11.9714

Sagiyeva, R,, Zhuparova, A., Ruzanov, R.. Doszhan, R., Askerov, A. (2018). Intellectual input of development by knowledge-based economy: problems of measuring in countries with developing markets. Entrepreneurship and Sustainability Issues, 6(2), 711-728. http:// doi.org/10.9770/jesi.2018.6.2(17)

Schuelke, L. (2018). A model for understanding the orders of magnitude of disruptive technologies. Technological Forecasting and Social Change, pp: 261-274. https://doi.org/10.1016/j.techfore.2017.09.033 
Schwab, K. (2016). The Fourth Industrial Revolution. Geneva: World Economic Forum. ISBN 194483500877.

Stankevičius, A., Lukšaitė, A. (2016). Transparent lobbying for sustainability: case of Lithuania. Entrepreneurship and Sustainability Issues, 4(2), 220-227. http://dx.doi.org/10.9770/jesi.2016.4.2(9)

Taubman, A., Wager, H., Watal, J. (2012). A handbook on the WTO TRIPS agreement. New York: Cambidge university press. URL: https://www.wto.org/english/res_e/publications_e/handbook_wtotripsag12_e.pdf

The Global Information Technology Report. Available on the Internet: https://www3.weforum.org/docs/GITR2016/WEF_GITR_Full_ Report.pdf

Tvaronavičienè, M. (2018). Toward efficient policymaking: forecasts of vulnerability to external global threats. Journal of Security and Sustainability Issues, 7(3), 591-600. https://doi.org/10.9770/jssi.2018.7.3(18)

Tvaronavičienè, M. (2019). Insights into global trends of capital flows' peculiarities: emerging leadership of China. Administratie si Management Public, (32), 6-17, https://doi.org/0.24818/amp/2019.32-01

WIPO Copyright Treaty (WCT) [Electronic resource] / World Intellectual Property Organization. - Electronic data. - Available on the Internet: http://www.wipo.int/wipolex/en/treaties/text.jsp?file id=295157

World trade statistical review, 2018). World Trade Organization. Available on the Internet: https://www.wto.org/english/res_e/statis_e/ wts2018_e/wts2018_e.pdf

World Intellectual Property Indicators (2018). Available on the Internet: https://www.wipo.int/edocs/pubdocs/en/wipo_pub_941_2018. pdf

Yang, J., Singh, M., Pita, Z., \& Storey, I. (2015). The relationship between strategic information systems planning facilitators and the success of South Korean organizations. Proceedings of 19th Pacific Asia Conference on Information Systems (PACIS 2015), Singapore, $1-17$.

Zambon, S. (2017). Intangibles and intellectual capital: An overview of the reporting issues and some measurement models. In The Economic Importance of Intangible Assets, (pp.165-196). Routledge. https://doi.org/10.1080/0963818032000162849

Zhou, Ch. (2018). State Capture and Technological Innovation during Institutional Transition: Empirical Evidence from Listed Companies in China's Growth Enterprise Market. Transformations in Business \& Economics, 17, No 2 (44), 180 -193

Vasyl PANKEVYCH, PhD (Law Science), Vinnytsia institute of trade and economics of Kyiv national university of trade and economics ORCID ID: orcid.org/0000-0003-0298-0033

Irina BILOUS, PhD (Law Science), Vinnytsia institute of trade and economics of Kyiv national university of trade and economics ORCID ID: orcid.org/0000-0003-0789-8282

Vitaliy OMELYNENKO, PhD (Econ), Associate Professor, Sumy State Pedagogical University named after A.S. Makarenko ORCID ID: orcid.org/0000-0003-0713-1444

Yeugene NAGORNYI, PhD (Econ), Leading Researcher, Sumy State Pedagogical University named after A.S. Makarenko RCID: ID: orcid.org/0000-0003-0756-8398

Andrii SUKHOSTAVETS, Ph.D., Assistant Professor, Sumy National Agrarian University

ORCID ID: orcid.org/0000-0002-4101-4105

Register for an ORCID ID:

https://orcid.org/register

This work is licensed under the Creative Commons Attribution International License (CC BY). http://creativecommons.org/licenses/by/4.0/ 